\title{
Odontogenic Tissue
}

National Cancer Institute

\section{Source}

National Cancer Institute. Odontogenic Tissue. NCI Thesaurus. Code C33794.

The tissue that forms the tooth. It consists of the dental pulp, dentin, enamel, cementum, odontogenic epithelium, and periodontium. 